DOI: $10.17516 / 1997-1370-0725$

УДК $372.881 .1+37.013$

\title{
Activity-Related and Sociocultural Grounds for Foreign Language Education of Adults who Lack Expressed Motivation for Cognitive Activity
}

\author{
Maksim V. Kochetkov*a,b, Olga G. Smolyaninovaa, \\ Alevtina N. Speranskaya ${ }^{\mathrm{c}}$ and Ekaterina M. Chebotareva ${ }^{\mathrm{d}}$ \\ ${ }^{a}$ Siberian Federal University \\ Krasnoyarsk, Russian Federation \\ ${ }^{b}$ Norilsk State Industrial Institute \\ Norilsk, Russian Federation \\ 'Lanzhou University \\ Lanzhou, China \\ ${ }^{d}$ Polotsk State University \\ Novopolotsk, Belarus
}

Received 14.08.2018, received in revised form 12.02.2021, accepted 06.03.2021

\begin{abstract}
The paper considers the problem of forced rather than self-actualized teaching of a foreign language to students, educators and representatives of other practical fields of activity. Theoretical and methodological backgrounds for solving this problem are revealed on the basis of the humanistic and activity-based traditions of psychological and pedagogical knowledge. Activity-related traditions are analyzed in regard with the potentialities of appropriate approaches to learning to stir cognitive interest while educational process. Humanistic traditions designed to individualize education are explored in the context of psycho-corrective capabilities of educational activity, its conformity to the world outlook, cultural needs and psychological characteristics of a learner. The practical side of this study consists of methodological recommendations on the application of Baitukalov's method of teaching foreign languages. Within the framework of Baitukalov's methodology, the activity-related aspect of sociocultural foreign-language immersion is actualized through feature films. Fragments from feature films are used for the humanization of education as well. In the paper it is also substantiated that the fragments of motion pictures recommended for memorization through role playing not only contribute to the development of the communicative competence, but also make the psycho-correcting effect on the learner's consciousness. The paper makes emphasis on fairy-tale stories, positive situations from films, where heroes overcome external circumstances successfully and change and grow personally. Besides, a characterization of a number of feature films is given. The criteria for the selection of feature films should be based on the individual characteristics of a

(C) Siberian Federal University. All rights reserved

* Corresponding author E-mail address: m-kochetkov@yandex.ru ORCID: 0000-0001-9882-6000 (Kochetkov); 0000-0002-5597-6348 (Smolyaninova); 0000-0002-0712-1337 (Speranskaya); 0000-0002-6272-6216 (Chebotareva)
\end{abstract}


person. It is recommended to unite the efforts of specialists for the experience exchange of using the feature films potential. The provision of «ecological safety» (that concerns ethics, moral, etc.) and aesthetics while selecting the certain fragments of film production for education purposes is asserted as the essential problem of the noted experience exchange. Further development of Baitukalov's methodology is suggested in the aspect of the teaching potential of feature films, as well as in increasing the efficiency of cognitive activity at the expense of equal time intervals between key semantic units (words, images, etc.) with at least threefold repetition of key information.

Keywords: schoolchild, adult, foreign language, foreign language education, feature film, culture, psycho-correction, sociocultural environment, speech activity, motivation, cognitive activity.

Research area: pedagogy.

Citation: Kochetkov, M.V., Smolyaninova, O.G., Speranskaya, A.N., Chebotareva, E.M. (2021). Activity-related and sociocultural grounds for foreign language education of adults who lack expressed motivation for cognitive activity. J. Sib. Fed. Univ. Humanit. Soc. Sci., 14(3), 341-350. DOI: $10.17516 / 1997-1370-0725$.

\title{
Деятельностные и социокультурные основания иноязычной подготовки взрослого человека при отсутствии выраженной мотивации познавательной деятельности
}

\author{
М.В. Кочетков ${ }^{\mathrm{a}, \text { б }}$ О.Г. Смолянинова \\ A.Н. Сперанскаяв, Е.М. Чеботарёваг \\ ${ }^{a}$ Сибирский федеральный университет \\ Российская Федерачия, Красноярск \\ ${ }^{\sigma}$ Норильский государственный индустриальный институт \\ Российская Федерация, Норильск \\ ${ }^{6}$ Университет Ланчжсо \\ Китай, Ланьчжоу \\ 'Полочкий государственный университет \\ Республика Беларусь, Новополочк
}

\begin{abstract}
Аннотация. Рассматривается проблема вынужденного, а не самоактуализированного обучения иностранному языку студентов, работников образования, представителей практических сфер деятельности. Теоретико-методологические предпосылки решения проблемы раскрываются на основании гуманистических и деятельностных традиций психолого-педагогического знания. Деятельностные традиции анализируются в связи с потенциальными возможностями соответствующих подходов к обучению инициировать познавательный интерес непосредственно в ходе обучения. Гуманистические традиции, призванные индивидуализировать образование, исследуются в контексте психокорректирующих возможностей
\end{abstract}


образовательной деятельности, ее соответствия мировоззрению, культурным запросам и психологическим особенностям обучающегося. Практическая сторона исследования состоит в методических рекомендациях по применению методики обучения иностранным языкам Байтукалова. В рамках методики Байтукалова актуализируется деятельностная сторона погружения в социокультурную иноязычную среду посредством художественных фильмов. Фрагменты из художественных фильмов используются и для гуманизации образования. Обосновывается, что рекомендуемые для ролевого игрового заучивания фрагменты кинофильмов способствуют не только речевой компетентности, но и психокорректирующему воздействию на сознание обучающегося. При этом особое внимание уделяется сказочным сюжетам, позитивным ситуациям из фильмов, где герои успешно преодолевают внешние обстоятельства, меняются внутренне. Из опыта практической работы дается характеристика ряда художественных фильмов. Раскрываются критерии выбора художественных фильмов, учитывая индивидуальные особенности человека. Рекомендуется объединить усилия специалистов в обмене опытом использования потенциала художественных фильмов. В качестве наиболее актуальной проблемы отмеченного обмена опытом выделяется обеспечение «экологичности», эстетичности при подборе тех или иных фрагментов кинопродукции для обучения. Дальнейшее развитие методики Байтукалова предлагается в аспекте обучающего потенциала художественных фильмов, а также в направлении повышения эффективности познавательной деятельности за счет равных промежутков времени между ключевыми смысловыми фразами (словами, образами и т. п.) при как минимум троекратном повторении ключевой информации.

Ключевые слова: школьник, взрослый человек, иностранный язык, иноязычная подготовка, художественный фильм, культура, психокоррекция, социокультурная среда, речевая деятельность, мотивация, познавательная деятельность.

Научная специальность: 13.00 .00 - педагогические науки.

\section{Introduction to the research problem}

The viability of Russian universities is currently determined by a set of high standards. One of them is connected with the international accreditation of educational organizations in respect of its implementing educational programs. In this regard, it is necessary to note the existence of «Model List of Criteria for the Russian-wide System of Assessing the Efficiency of Higher Education Institutions». The recommendatory status of the document is perceived as a strict requirement by the pedagogical community. One of the criteria for this document is «the proportion of students studying at educational programs of higher professional education that have international accreditation» (Primernyi perechen' kriteriev ...: 1.2).

Recently, such an international accreditation instrument as the «CDIO Initiative» has grown in importance in the world (Sinenko, Pal'ianov et al., 2016). In January 2014, Siberian Federal
University joined it as well. Within the CDIO concept, the implementation of educational programs is focused on project activities integrated with production. For these purposes, $12 \mathrm{CDIO}$ standards defining the principles of design and implementation of educational programs were developed and approved in 2004. The standards suggest the ability to be conscious of necessity for lifelong education, teamwork, project activities, communication in a professional environment and society, including the world's sociocultural space.

The CDIO concept is characterized by the following metaprinciples: "Conceive Design - Implement - Operate» real-world systems, processes and products on the international market (Primernyi perechen' kriteriev...).

Consequently, nowadays, modern sociocultural challenges projected onto higher education are associated with the effective teach- 
ing of foreign languages to both students and faculty. Much the same is true for representatives of other practical spheres of activity as well. Besides, the need for learning a foreign language is often caused by stressful, extraordinary circumstances for a person. In other words, it is difficult for a representative of a practical sphere of activity to predict the need for interaction with foreign colleagues. Thus, the effective teaching of a foreign language to future specialists or practitioners becomes more and more relevant.

In passing, we note that the problem of teaching a foreign language to an adult is often determined by the low efficiency of school education. It also should be noticed that one of the obligatory examinations for graduates from the $9^{\text {th }}$ form will be a foreign language, "All graduates from $11^{\text {th }}$ form will have to take it from 2020» (Arsent'ev, 2015). The reason for such close attention to a foreign language as a subject among other school subjects remains an open issue for us. Anyway, the sharply increased relevance of foreign language learning for the school graduate is indisputable.

Now, the method of teaching foreign languages is paid the closest attention. Perhaps, it is difficult to find any other area of training that would have so many widely popular teaching methods. At the same time, even the average state school graduate that is ignorant of the teaching methodology understands that students spend their time on learning foreign languages inefficiently.

As it has been stated, there is a huge number of good training aids and resource books on teaching foreign languages. They seem to allow coping with grammar rules, reading, popular communication topics. Why, then, do people learn a foreign language for years, being able to make up sentences, comprehend grammatical constructions, but remaining incapable of speaking fluently and as a result forming psychological barriers and complexes?

Learning grammar is very significant. It is extremely difficult to teach someone to speak a foreign language from scratch without understanding the basics of grammar. At the same time, it is known that if a person of any age finds oneself in a foreign sociocultural environ- ment and is completely immersed in it, learning a foreign language becomes more efficient even for the one with low cognitive abilities. Of course, in this case, an adult person is unlikely to be able to write sonnets in the target language like Shakespeare did, but to express your thoughts and needs in a foreign language is something that almost everyone can do.

\section{Theoretical grounds for research}

What principal approaches associated with the initiation of cognitive interest in learning a foreign language can be offered by psychological and pedagogical knowledge?

Western experience founded on a humanistic conceptual basis and presented in the studies of A. Kombs, A. Maslow, K. Patterson, K. Rogers, etc., provides a person with emotional emancipation and focuses on freedom of choosing the way of cognition. The function of educational structures in this case is determined by the creation of conditions for self-actualization of the "self» by an individual, the realization of the aspirations and creative potential. Theorists and practitioners of the humanistic school tend to take into account the complexity of man's mental world, the selfworth of individuality, its uniqueness and intentions. Strictly outlined systematic training is considered to be contrary to the vectors of humanistic education, as it prevents freedom of self-realization.

There is another approach in our national tradition in psychology and pedagogy (P. Ya. Galperin, V. V. Davydov, A. N. Leontiev, N.N. Nechaev, A.I. Podolsky, N.F. Talyzina, etc.). The peculiarity of the development and self-development of a person, especially of an adult, is associated with the rejection of explicit, intrusive influence from the outside. Drawing on national traditions (Leont'ev, 1946), when learning a foreign language, we proceed from the fact that the interest to learning can be initiated after or during the practical and applied activity, that allows the content of the studied material to become relevant for a person (Kochetkov, Kovalevich, 2020).

In the latter half of the past century famous Russian scientists (B. Ts. Badmaev, P. Ya. Galperin, V. V. Davydov, N. N. Nechaev, 
A. I. Podolsky, N. N. Talyzina, etc.) developed the theory of step-by-step formation of mental actions. They assumed that it is necessary to teach how to apply knowledge to practice (in our case, to communicate in a foreign language). For the last fifteen years, the reforming of the Russian higher school has been carried out toward such a super-category as competence. This category is considered to come from the West, although the competence-based approach in its practice-oriented focus differs little from the practice-oriented essence of the national theory and practice of the step-by-step formation of mental actions.

We shall consider the practice-oriented aspect of educational activity in detail. Language practice in the sociocultural environment of native speakers is considered to be the most effective. However, such a dive is not always possible. More accessible are audio-visual possibilities of immersion into the sociocultural environment through feature films. We consider sociocultural immersion into language practice through feature films to be an activity side of cognitive activity. In other words, the activity side of the student's cognitive processes is learning, focused on speech practice in the sociocultural foreign language environment.

As it has been noted, the efficiency of forming influence on the development of an adult depends on the involuntary influence of the educational environment. In this case competences are formed as a result of adaptation to a sociocultural educational environment structured in a certain way.

The concept of «competence» is not applicable to all mental and sensuous abilities that are realized in human activity, which is a significant disadvantage of the competence-based approach (Anderson, 2014; Fleming et al., 2016; Hammershøj, 2014; Eisner, 2003). E. Eisner argues, for example, that being non-alternative and linear, the competence-based approach oppresses the imagination and figurative processes in general (Eisner, 2003: 198). According to the well-known culturologist Ziauddin Sardar, the efficiency of modern man's life is primarily associated with his imagination (Sardar, 2010: 443). However, visual-emotional perception of the person is suppressed by the widespread im- plementation of standardization and the drive for permanent measurement of results of educational activity (Greene, 2013; Welsh et al., 2013; Kochetkov, Chebotareva, 2017; Kochetkov, Chebotareva, 2020).

Thus, the competence-based approach with its focus on all-round diagnosis and regulation, with its oppression of imagination and the emotional processes associated with the experience of diverse life situations, does not contribute to the active introduction of feature films as the main means of education.

On the basis of two ways of life described by S.L. Rubinshtein (Rubinshtein, 2000), the model of practice-oriented teaching can be represented as a model of adaptive behaviour and the model of professional development (Rubinshtein, 2000). Also, three functional levels of human adaptation are distinguished: physiological, mental and social (Chernilevskii, Moroz, 2001). It should be noted that the current interpretation of the concept of adaptation implies not only the adaptation of an individual to the environment, but also the individual's active role in its transformation (Novikov, 2013).

When taking into consideration the intended meaning of the concept of adaptation, agreeing to apply pedagogical innovations in practice and implement certain models of sociocultural educational environments (in our case, feature films as the environment for learning a foreign language) in work, the individual gradually adapts to the content that fills in the innovative forms. The interiorization of the content is associated with its completely different interpretation, the creation of new forms of education and self-education and the creation of sociocultural educational environment (self-selection for self-study of feature films, episodes from films for learning, etc.).

This approach is called sociocultural in the present study. Now in the Russian education it is the leading competence-based approach (competence-based paradigm). In S.L. Rubinstein's practice-oriented training model, the model of adaptive behaviour is correlated with the sociocultural approach, and the model of professional development - with the competence-based approach. We should stress that according to N.G. Agapova's statement, 
«The only 'right' paradigm of education is absent there, that is, the simultaneous existence of several paradigms is the characteristic feature of education today; within one paradigm different modes of education could exist (co-exist) and develop; there could be integration and synthesis of different modes and paradigms in the frame of the single educational space» (Agapova, 2008: 312).

The main purpose of adaptive behaviour model is the emergence of interest in a foreign language, motivated learning of a foreign language. The description of a single learning process in the form of adaptive behaviour model and professional development model is rather conditional. Therefore, it is fair to consider the same feature film to be a means of implementing a model of adaptive behaviour, and a means of professional development. Thus, the methodical techniques revealed by us in the future are not intended to replace, but to complement the existing technologies of foreign language teaching, which are developed within the framework of the competence-based paradigm.

\section{Activity-related bases for research}

As noted earlier, the activity-related side of cognitive action is understood as foreign language practice, integrated into life situations by watching relevant films (primarily feature films).

In order to immerse in a foreign-language sociocultural environment, let us turn to the possibilities of one of the known methods Baitukalov's method (Baitukalov, 2008). In our opinion, the key element of this method is the use of films. However, we will not explicate all the features of the methodology in this paper; besides, the thesis about films as its integrating core is controversial, since the methodology includes neurolinguistic programming, takes into account the features of representative human systems, the patterns of work of both consciousness and subconscious, audio learning, group methods of teaching, etc. (Baitukalov, 2008).

Such significant attitude to the film as an integrator of learning stems from its opportunities for creating an active sociocultural educational environment for foreign language learning. When a person has already got some knowledge base of the grammar and vocabulary of the language they study (e. g. how the sentences are structured, how speech is formed, at least in general terms), then learning a foreign language from video films can be started. In fact, it is proposed to use the possibilities of films for a deep immersion into a foreign language environment. An interesting plot and artistic features of films conduce such an immersion and interest in the language. The author of the methodology suggests not only memorizing, but also role-playing certain fragments of films. As a result, cognitive activity is significantly increased, its persistence is manifested. Nowadays, subtitles of most foreign films are quite available on the Internet, as well as the films themselves. Subtitles can be learned, which contributes to the effectiveness of modelling speech behaviour in all its aspects, that is, it is close to life situations (emotionally, visually, thematically, in terms of the most used language constructs, etc.). Our working experience of pedagogical activity has shown that pronouncing linguistic structures together with the actors of the film (real native speakers!) and then the independent use of them in the speech, when playing the scenes, really helps. Thus, a foreign language «settles down», «fixes» in the head in a natural manner.

The natural conformity of the method can be justified by the analogy with the process of the language acquisition by little children: they begin to speak only by copying adults who already speak the language. They observe and repeat not only language patterns, but also many actions that activate an intuitive understanding of unknown words and phrases and provides a high emotional background of cognitive activity, which, as it is known, contributes to the productivity of thought reactions.

For an adult, finding an authoritative interlocutor, like a parent for a child, is not easy. Films, taking into account personal preferences, just provide this opportunity. After all, in real life it is not always possible to talk, for example, with Angelina Jolie or Julia Roberts, for several hours and to observe their reaction to various life situations. Therefore, the choice of films for learning, especially at the initial stage, 
is a difficult task for a person who teaches a foreign language to an adult. On the other hand, there is a possibility for co-creation, which favours an interest towards learning a foreign language.

At the stage of self-education, an adult is free to choose films that are important for them. This is the essence of methodological creativity in this case, which precisely corresponds to the humanistic messages of educational activity. And it is necessary to understand that there are serious requirements to the psychological content of situations from the film and the quality of foreign speech. The memorization and reproduction of fragments has a significant influence not only on the language competence of a person, but also on their attitude, communication settings, and current attitudes. As a rule, in all films there are scenes where the main character «gets into a mess», that is, there are destructive scenes in respect of influence on the person's attitude. Therefore, it is important to choose for memorization the parts of films, associated with the states of success, overcoming insecurities, accepting themselves and others.

\section{The examples of films}

\section{for sociocultural foreign immersion}

It should be noted that, unfortunately, the positive and aesthetically sustained foreign films are in great deficit. After all, the modern average viewer is not inclined to watch the film that has no twisted plot, clear humour or exciting scenes of fight in its numerous manifestations, let alone the exploitation of the «basic instinct». Where there's demand, there's supply. As a result, for an aesthetically sophisticated person it is difficult to choose a good feature film, and even some fragments.

With this consideration in mind, we will list some films that could be recommended for training (based on our practical experience).

«When in Rome», 2002. The film starts with the scene, where the main heroine's boyfriend breaks up with her publicly, in front of her colleagues. At the beginning of the film the young woman is extremely depressed. But then, as a result of a happy accident, all the men are at her feet, the woman acquires self- confidence, marries for love, relations at work improve dramatically.

«Yes-man», 2008. As in the previous case, at the beginning of the film everything goes wrong, the main character's wife leaves him. Then he finds love and happiness with another woman, recovers his poise with his ex, becomes successful at work. His mental outlook changes.

«The Holiday», 2006. In the beginning, the story line is connected with quarrels and breaches. Therefore, the use of the entire film for training purposes is not advisable. In the second part of the film, the heroines find true love and become happy. Some fragments of the second part of the film are quite appropriate to use for language learning.

«Journey to the centre of the Earth», 2008. This film is very good for teaching male students, both adults and school children. In the beginning, the main character is unsuccessful, since his lectures are unpatronised, and the results of many years of work are not in demand - the scientific laboratory is closed. Considering the above, it is better not to use the beginning of the film for training according to Baitukalov's method. Next in the plot, the man has to change his lifestyle: he goes on a long journey to sort out with the testimony of one of the sensors in Iceland, and to find out the fate of the disappeared brother as well. The young man meets a beautiful woman, the guide, and together with his nephew they fall underground into the mine and then into other quite exotic places. After that, they find diamonds and a lot of amazing things, overcoming many dangerous obstacles, revealing the enormous potential necessary for survival. The main character becomes not only rich and falls in love mutually, but also changes internally, turning from a loser into a superhero. This film is suitable for memorization especially: there are various interesting topical units containing not so many complex phrases and rare words. In this film, the sentences are basically simple and short, so they are easy to memorize.

«Princess' Diaries», 2001. The first part of the film, where the heroine is pursued by ill luck (being the ugliest in class, the object 
of laugh and bulling, etc.), is arguable to use for learning. It is necessary to notice some episodes, where a handsome classmate starts paying attention to her and in the end turns her into ridicule. These parts are not worth taking for training as well.

However, there are some positive and interesting fragments, which may be used for educational purposes, for example, in the final part of the film, where the princess decided to collaborate with her grandmother, the queen, there was a climax ball, and she deservedly becomes a «star», overcoming many insecurities, changing outwardly. From the linguistic point of view, the film is very useful due to the grandmother's speech: the language constructions are perfectly correct, without slang, the pronunciation is flawless and, most importantly (especially in films), the rate of speech is rather slow. The latter can be explained by the nature of the grandmother's the role, the queen, as a titled and highly cultured person.

"Another Cinderella Story», 2008. The title of the film speaks for itself. It is recommended to learn the parts that the student would like to use in real life, e. g. topics of dialogues, the atmosphere during the ball, friendship, ways of reconciliation, overcoming difficult circumstances. Like the previous film, this one is suitable for girls, it not only improves their pronunciation and grammar and expands the vocabulary, but also influences their demeanour: they become more confident, even their body posture is corrected (from work experience).

The same is true for the next film, «Mirror Mirror...», 2012 with Julia Roberts as the Queen. However, there are also some stories for teaching boys. It should be noted that the fairy-tale stories, commented on in the aspects of teaching boys and girls, do not lose their relevance to adult learners. In the films aimed at children's audience, there are more fragments with the correct speech and slow pace. As practice shows, stories for children are interesting to adults and promote very high results. They return the adults into childhood; a deep creative component of a person is manifested; as a result, an adult overcomes insecurities and is easily immersed in the linguistic environment, which contributes to the efficiency that cannot be commensurated with previous attempts to form a foreign language competence.

On this basis, we emphasize the importance of associating oneself with the positive characteristics of the main characters and with victories in their lives once again. In some cases of our practical work, its marked effect (associating, transferring) can be compared with many years of work with a psychologist, namely towards development and correction of personality traits. In this connection, among the psychological mechanisms, we should point out the features of the work of subconsciousness: it does not make great distinctions between reality and game situations, when fixing the corresponding model of behaviour. A number of psychological corrective and forming methods of work with both children and adults are based on the understanding that for a successful socialization a boy needs to go the way of a hero in childhood and the girl - the way of a beauty. That is, without the marked dominant accents, the education of a girl (or a boy) that is good, obedient and comfortable for a society may later lead to difficulties both in personal life and career. After all, it is known that not all smart girls feel happy, which cannot be said about those who feel attractive. With regard to boys, this is also true, although in this case, the success after overcoming external circumstances, the obstacles in respect of competitive aspect, becomes more important.

\section{Theoretical and practice-oriented perspectives of the research}

We sought to demonstrate not so much the peculiarities of specific feature films, but to reveal the universal criteria for their evaluation. Therefore, the submitted descriptions of the films do not claim to be a balanced assessment of the enormous quantity of modern film production. It provides the opportunity for the experience exchange between professionals, encouraging foreign language learning as a result of the immersion into sociocultural environment of the film. The most essential problems during such an experience exchange are the ob- 
servance of «ecological safety» (that concerns ethics and moral, etc.) and aesthetics in the selection of certain fragments of films for language learning, conformity of these fragments to the world outlook and cultural needs of an individual, and the use of the potential of the trainee's abilities for psycho-correction.

As for adult learners, there is one more positive aspect of using films according to Baitukalov's methodology: the additional motivation for learning a foreign language is determined by the interest in teaching their own children, as one of the approaches to such learning becomes available.

In the context of neurolinguistic programming, intrinsic coding, self-programming, the further development of the methodology is determined by the consideration of such factors of effective cognitive activity as equal time intervals between key semantic units (words, images, etc.) with threefold repetition. This approach corresponds to the psychophysiological patterns of effective cognitive activity of a person and is not practically reflected in Baitukalov's methodology (Baitukalov, 2008). Although, we should take into account the fact that psychophysiological patterns could substantially increase the effectiveness of teaching foreign languages. Multiple (at least, triple) reproduction of educational material with approximately equal time intervals is believed to be effective not only in educational activities, but also in the neurological practice of working with mental disorders (in the latter case, it is not about training but about psycho-corrective material). We emphasize that multiple repetition is contained in the methodology. We just actualize at least threefold reproduction of the educational material in the aspect of approximately equal time intervals between the key semantic units (images). This means that training material is the most significant, which, in turn, is very individual and situational for each student.

\section{Conclusion}

The study focuses on the definition, theoretical assumptions and methodological characteristics of forced rather than self-actualized learning of a foreign language. Activity-based immersion into the sociocultural foreign language environment is designed to initiate motivated learning of foreign languages directly in the learning process. To do this, it is proposed to use the potential of feature films. Another theoretical basis in the study was the humanistic ideas of individualization of psychological and pedagogical practice. In this regard, the focus is also on feature films as a means of individualization of education. Based on the example of specific feature films, the authors revealed the criteria for their choice, taking into account the worldview, cultural and psychological characteristics of the sudent. Special attention is paid to psycho-correcting possibilities of teaching foreign languages using feature films and the importance of fairy-tale storylines for psychocorrection of both schoolchildren and adults.

\section{References}

Agapova, N.G. (2018). Paradigmal'nye orientatsii i modeli sovremennogo obrazovaniia (sistemnyi analiz $v$ kontekste filosofii kul'tury) [Paradigm orientations and models of modern education (system analysis in the context of culture philosophy)]. Ryazan, RGU, $364 \mathrm{p}$.

Anderson M. (2014). The challenge of post-normality to drama education and applied Theatre. In Research in Drama Education: The Journal of Applied Theatre and Performance, 19, 110-120.

Arsent'ev, A. (2015). Minobrnauki ob"'iavilo voinu slabym vuzam [The Ministry of Education and Science has declared war on weak universities]. In Kommersant [Kommersant]. Available at: http://www. kommersant.ru/doc/2696986 (accessed 27 March 2015)

Baitukalov, T.A. (2008). Bystroe izuchenie inostrannogo iazyka ot angliiskogo do iaponskogo [Fast learning of a foreign language from English to Japanese]. Moscow, Ripol Klassik, $160 \mathrm{p}$.

Chernilevskii, D.V., Moroz, A.V. (2001). Kreativnaia pedagogika i psikhologiia [Creative pedagogy and psychology]. Moscow, MGTA, $301 \mathrm{p}$. 
Eisner, E.W. (2003). The arts and the creation of mind. In Language arts, 5 (80), 340.

Fleming, J., Gibson, R., Anderson, M., Martin, A.J. \& Sudmalis, D. (2016). Cultivating imaginative thinking: teacher strategies used in high-performing arts education classrooms. In Cambridge Journal of Education, 46 (4), 435-453. DOI: 10.1080/0305764X.2015.1064097.

Greene, M. (2013). The turning of the leaves: Expanding our vision or the arts in education. In Harvard Educational Review, 83, 251-252.

Hammershøj, L.G. (2014). Creativity in education as a question of cultivating sensuous Forces. In Thinking Skills and Creativity, 13, 168-182.

Kochetkov, M.V., Chebotareva, E.M. (2017). Creative and Innovative Educational Paradigm and Acmeological Approach to the Development of a Student as a Subject of Professional Activity. In Journal of Siberian Federal University, 10 (2), 177-188. DOI: 10.17516/1997-1370-0018

Kochetkov, M.V., Chebotareva, E.M. (2020). Intellectual Maturity as Goal Setting in the Global Anthropological Crisis (In the Context of Russian Socio-Cultural Reality). In Progress in Education, 65, 143 174 .

Kochetkov, M.V. \& Kovalevich, I.A. (2020). Specific features of educational and pedagogical discourse in the context of anthropological challenges: socio-cultural approach. In Journal of Siberian Federal University, 13 (2), 268-277. DOI: 10.17516/1997-1370-0578

Leont'ev, A.N. (1946). Psikhologicheskie voprosy soznatel'nosti ucheniia [Psychological issues of teaching's consciousness]. In Izvestiia APN RSFSR [Proceedings of the Academy of Pedagogical Sciences of the RSFSR], 7. Available at: http://elib.gnpbu.ru/text/izvestiya-apn_vyp7_1947/ (accessed 26 February 2017)

Novikov, A.M. (2013). Pedagogika: slovar' sistemy osnovnykh poniatii [Pedagogy: dictionary of basic concepts]. Moscow, Izdatel'skii tsentr IEHT, $268 \mathrm{p}$.

Primernyi perechen' kriteriev obshcherossiiskoi sistemy otsenki effektivnosti deiatel'nosti vysshikh uchebnykh zavedenii. Minobrnauki Rossii [The approximate list of criteria for the Russian-wide system of assessing the efficiency of higher education institutions. The Ministry of Education and Science]. Available at: http://fgosvo.ru/news/8/174 (accessed 6 November 2017)

Rubinshtein, S.L. (2000). Osnovy obshchei psikhologii [Fundamentals of General Psychology]. SaintPetersburg, Piter, 712 p.

Sardar, Z. (2010). Welcome to postnormal times. In Futures, 5 (42), 435-444.

Sinenko, V. Ya., Pal'ianov, M.P., Gafurova, N.V. \& Osipova, S.I. (2016). Problemy razrabotki obrazovatel'noi sistemy v ramkakh kontseptsii vsemirnoi initsiativy CDIO [Problems of development of educational system in the framework of the worldwide CDIO initiative]. In Sibirskii uchitel' [Siberian teacher], 105 (2), 26-30.

Welsh, M.E., D’Agostino, J.V. \& Kaniskan, R. (2013). Grading as a reform effort: Do standards-based grades converge with test scores? In Educational Measurement: Issues and Practice, 2 (32), 26-36. DOI: 10.1111/emip.12009. 